DOI: $10.36910 / 6775-2524-0560-2020-38-08$

UDC 621.391

${ }^{1}$ Мороз Борис Іванович, Dr. Sc. (Tech.), Prof.;

https://orcid.org/0000-0002-5625-0864

${ }_{1}^{1}$ Сироткіна Олена Ігорівна, Cand. Sc. (Tech.), Assoc. Prof.;

https://orcid.org/0000-0002-4069-6984

${ }_{1}^{1}$ Марочко Артем Миколайович, Postgraduate Student.

${ }^{1}$ Dnipro University of Technology, Dnipro, Ukraine.

\title{
RECOGNITION SYSTEM FOR INCREASING BUSINESS POTENTIAL FROM IN-STORE CUSTOMERS
}

Мороз Б.І., Сироткіна О.І., Марочко А.М. Система розпізнавання для підвищення ефективності бізнесу при роботі $з$ покупцями в магазині. В даній роботі представлено комплексний алгоритм створення системи розпізнавання користувача 3 метою ідентифікації покупців, а також збору, складування, аналізу і досліджень торгової організації 3 синхронізацією і виводом в програму, встановлену на ПК або смартфон.

Ключові слова: Аналітична система, ефективність торгової організації, алгоритм аналізу і досліджень, моделювання і прогнозування результатів.

Мороз Б.И., Сироткина Е.И., Марочко А.Н. Система распознавания для повышения эффективности бизнеса при работе с покупателями в магазине. В данной работе представлен комплексный алгоритм создания системы распознавания пользователя с целью идентификации покупателей, а также сбора, хранения, анализа и исследований торговой организации с синхронизацией и выводом в приложение, установленным на ПК или смартфон.

Ключевые слова: Аналитическая система, эффективность торговой организации, алгоритм анализа и исследований, моделирование и прогнозирование результатов.

B. Moroz, O. Syrotkina, A. Marochko. Recognition system for increasing business potential from in-store customers. This paper presents a comprehensive algorithm for creating a user recognition system to identify customers as well as collect, store, analyze and research data from a business. Its main features include synchronization with, and output to, an application installed on a PC or smartphone.

Keywords: Analytical system, effectiveness of the trade organization, algorithm analysis and research, modeling and forecasting results.

Introduction and formulation of the problem. Any analytics begins with collecting initial data. Therefore, only after receiving all the data can we begin the analytical part. In our case, the following items are input data:

1. The number of potential buyers who enter the shop;

2. Their movement along the area of the outlet (heat map);

3. Focus on specific goods (the time they spend at a counter or in a given area);

4. Total time spent and time zones of the store (hours in which most customers visit);

5. The amount of money spent to purchase the goods within certain hours, from certain counters and in general.

Aim of the article. The aim of the paper is to describe the concept of collecting information, taking into account different conditions. We would like to offer an effective algorithm and methodology for collecting information about the work of a business organization.

Analysis of previous experience in the development of similar systems. There are currently enough ideas to recognize the number of visitors entering the store:

3D-ASSIS [1] is a video system used to collect information and further analyze attendance data at shopping venues, and theme clubs. It can also be used in public transportation.

FindFace [2] is face recognition technology developed by NtechLab specializing in neural network solutions. Based on this technology, the company presents a number of solutions for various industries across the country.

NeoFace [3] is high performance face recognition software that delivers the most accurate results in the quickest way possible for the most demanding use of face recognition in real time. It can also be used following a specific event.

However, in spite of the technologies already implemented, the question of creating a unified system of tracking and identifying users (with the subsequent transfer of information to the processing base) remains open and requires improvement for specific situations. 


\section{Disadvantages of identification systems:}

1. Dependence on high quality, expensive equipment;

2. High cost when using different systems to increase efficiency;

3. The need to retrofit doors to accommodate monitoring equipment;

4. It is an imperfect system operating at less than $100 \%$ efficiency;

5. The inability to screen out non-customers (such as employees).

\section{Advantages of the automated system:}

1. Unity of the system;

2. More than $90 \%$ efficiency;

3. Wide variation of parameters (the algorithm is not affected by age differences, lighting, head position, etc.);

4. In the future, it is possible to increase the indicators and therefore increase the efficiency of business activities;

5. Identifying people from the "Black List" at the entrance to the outlets.

\section{Main part}

In order to create a user authentication system, it is necessary to complete the following tasks:

1. What technical means to use;

2. How to distinguish between users and employees of the store and other staff;

3. How to determine the focus of buyers (by time-of-stay or by the number of people in certain areas);

As a solution to the first problem, we can use the following user-identification scheme. The first element of our hierarchy will be sensors mounted on doors or frames.

Sensors capable of calculating user entrance / exit is shown in Fig. 1.

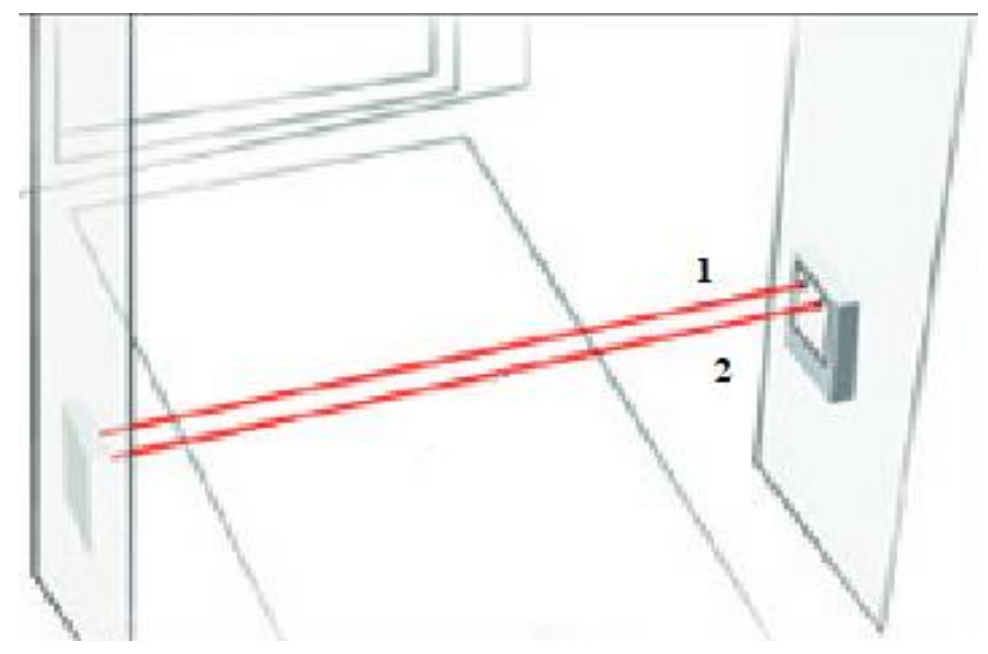

Fig. 1. User entrance / exit sensors

These sensors are able to recognize the entrance and exit of users when they cross an infrared ray. When the first ray and the second one are crossed, the system registers "entrance" of a customer, otherwise it registers "exit". These sensors have several disadvantages [4]. First, there may be a situation where the customer first crosses the second ray, such as swinging his arm or bag over the top. Secondly, with a large flow of customers, the efficiency of the sensors decreases. Therefore, the second stage of our scheme will be a 3D sensor mounted directly above the entry/exit area, which in turn can differentiate the number of customers in that area. The 3D sensor mounted above the zone is shown in Fig. 2. 


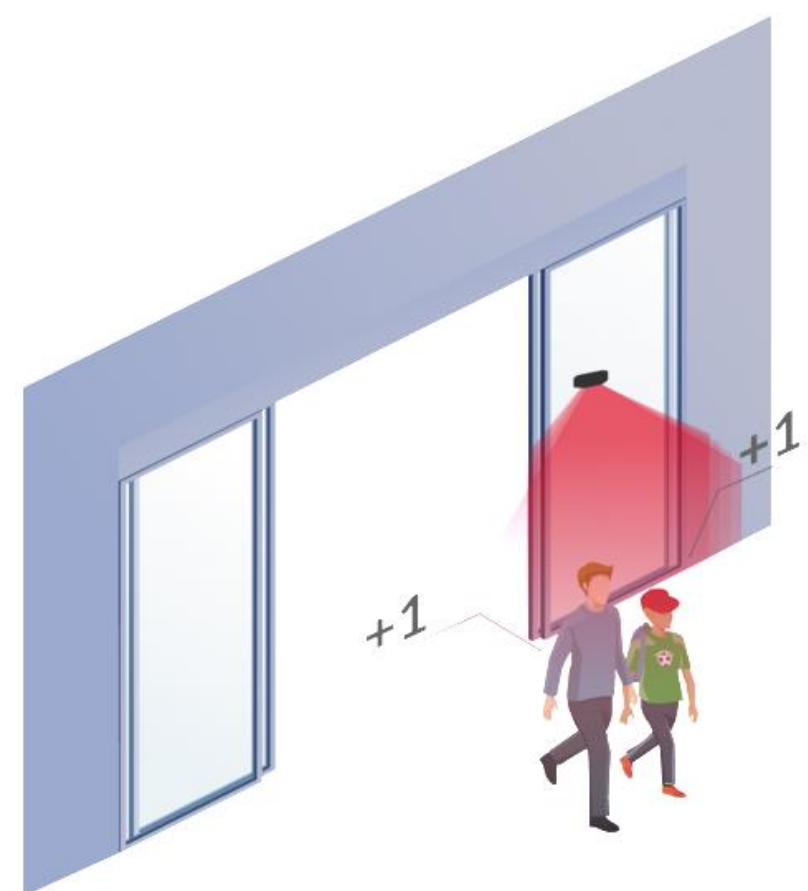

Fig. 2. 3D sensor above the entrance area

Thanks to this sensor, recognition efficiency increases to about $95 \%$, but this indicator can be improved, because under some circumstances this sensor may not be very effective when customers walk in with an umbrella or small children [8]. Therefore, in order to reach greater efficiency, we can go to the third element called "cameras", which are capable of recognizing images. In order to effectively identify the customer, we need two cameras, one on the left and the other on the right [9]. In this case, when the customer comes in with his head turned or with his hat on and the camera is unable to recognize him, it goes to zero. The location of the cameras in space is shown in Fig. 3.

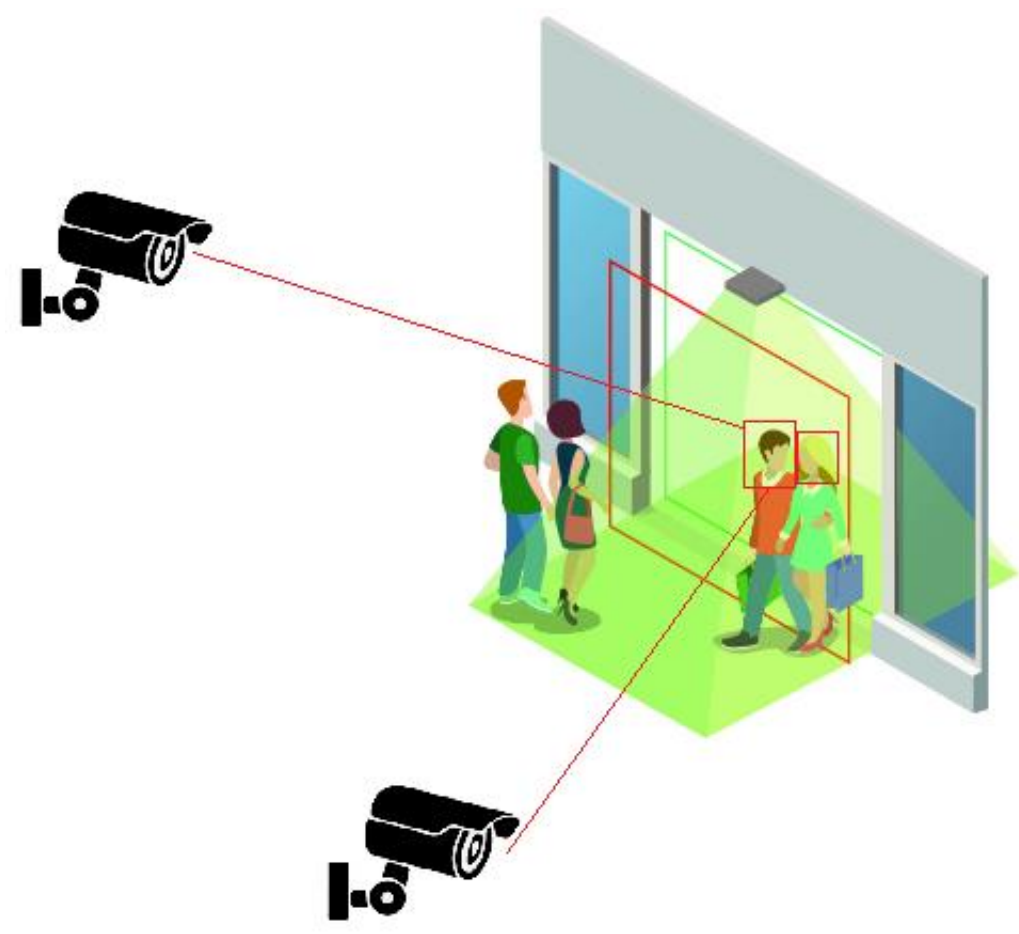

Fig. 3. Location of cameras in space for maximum identification efficiency 
The second task of distinguishing between customers and employees can be solved by using one of the following solutions:

1. Put a special ID badge on the outerwear of employees, such as a symbol on a T-shirt that will lock the camera and ignore these images;

2. Create a system of "smart gestures" that can be used by employees at the entrance to correctly identify them [5];

3. Enter employees in the database so they will be recognized correctly at the entrance [6];

4. Provide them with special cards that will work as keys and be recognized by sensors when putting them at a certain distance;

5. Track movements, and in case of crossing "service areas", ignore them and record them into the "employees" category [7].

The solutions with the keycard and ID badge are shown in Fig. 4. The analysis of the zone and the identification of the person as an employee is related to his position in the space and being in a special zone are shown in Fig. 5.
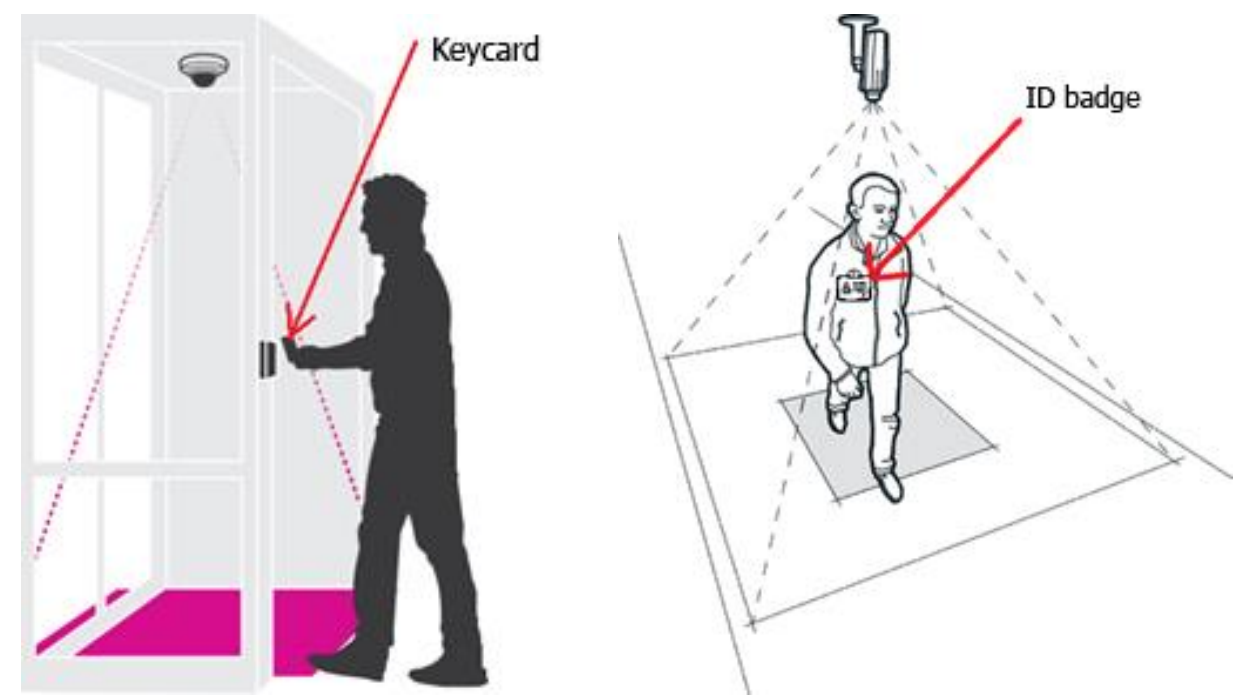

Fig. 4. Key card and ID badge to correctly identify employees

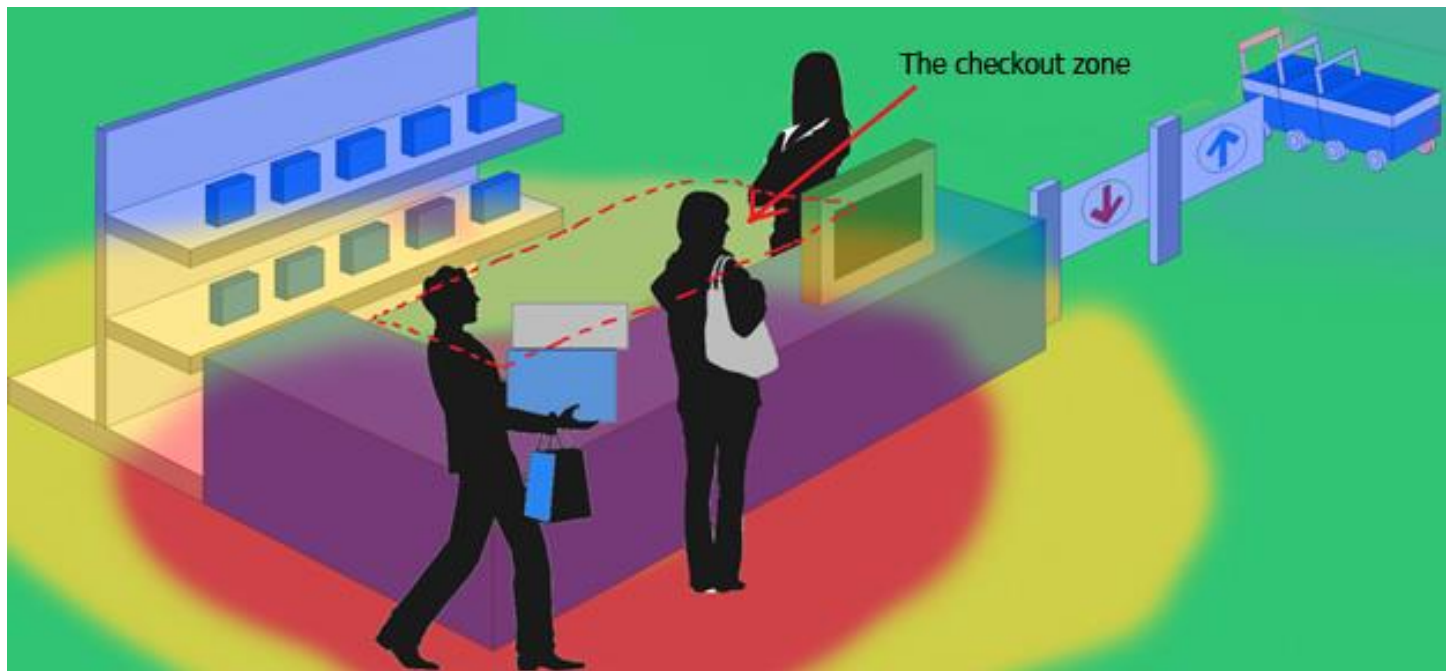

Fig. 5. Analysing the checkout zone and recording the administrator to the "employee" group

Customers' focus on the product will also be determined by thermal cameras. Their indication will be based on the time the customer was near the counter and the number of customers in the area. The redder the area, the more people were there [10]. This is shown in Fig. 6. 


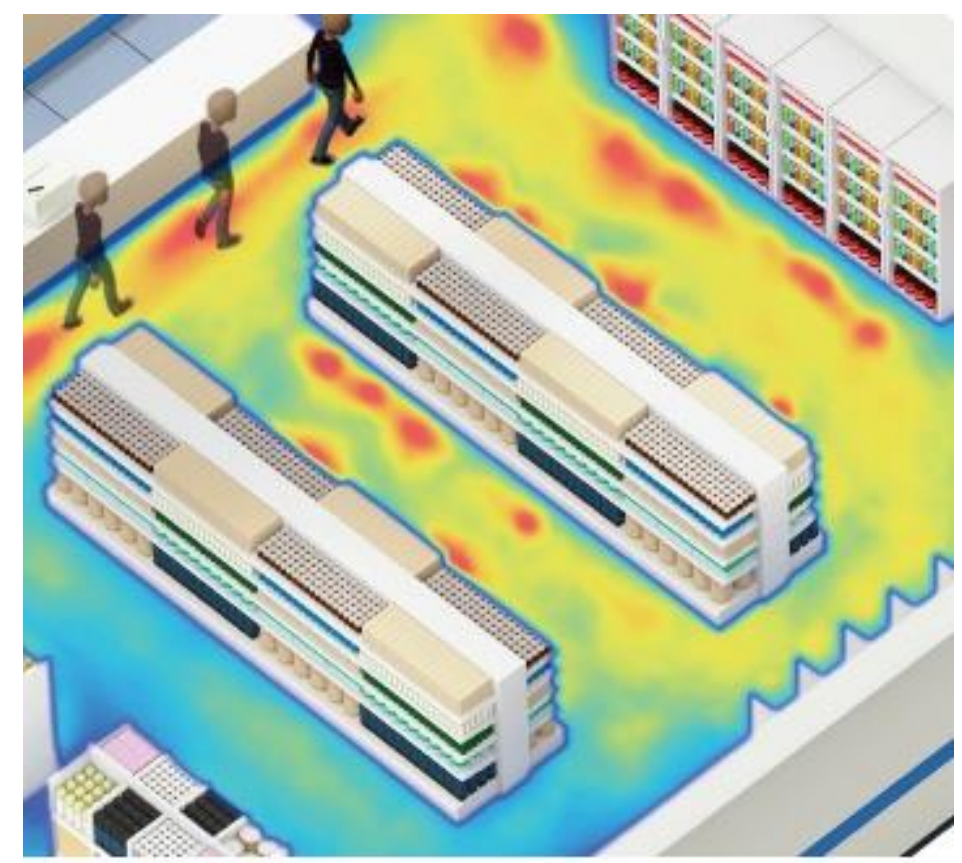

Fig. 6. Thermal zones indicating the most popular areas in the store

Conclusions and prospects for further development. We considered the concept of information collection taking into account various possible scenarios. There are several options for implementing a camera system that can identify users and their preferences.

\section{References}

1. 3D ASSIS. [Electronic resource] // URL https://megacount.ru/3dassis.html

2. Deductor. [Electronic resource] // URL https://findface.pro

3. Amazon GO. [Electronic resource] // URL

https://www.nec.com/en/global/solutions/safety/face_recognition/NeoFaceWatch.html

4. Asit Kumar Datta, Madhura Datta, Pradipta Kumar Banerjee: Face Detection and Recognition: Theory and Practice, 2016. P. 152-159.

5. Manisha Omprakash: implementing face recognition in matlab, 2018. - P. 120-130.

6. Federica Marcolin: Neural Networks and Deep Learning, 2018. - P. 100-120.

7. Kelly Gates: Our Biometric Future: Facial Recognition Technology and the Culture of Surveillance, 2011. - P. 62-70.p.

8. Laura E. Miller, Ray Miller: That's Customer Focus!: The Overworked and Underappreciated Manager's Guide to Creating a Customer-Focused Organization, 2008. - P. 69-74.

9. Face++. [Electronic resource] // URL: https://www.faceplusplus.com/

10. DeepFace. [Electronic resource] // URL: https://deepface.ir/

Reader: Oleg Bajbuz, Dr. Sc. (Tech.), Prof., head of the Department of Mathematical Support of Calculating Machines at Oles Honchar Dnipro National University. 